\title{
Determinants of disagreement with female genital mutilation/cutting of future daughters and awareness of the ban among Egyptian university students
}

\author{
Aya Mostafa ${ }^{{ }^{*}} \mathbb{D}$, Shaimaa Ashmawy Gaballah ${ }^{2}$ and Ghada Essamaldin Amin ${ }^{1}$
}

\begin{abstract}
Background: Egypt is one of three countries where half of female genital mutilation/cutting (FGM/C) victims live, despite its ban. To inform policy on the awareness of this ban and the impact of other interventions, this study sought to assess FGM/C-related knowledge, perceptions, and determinants of disagreement with FGM/C and circumcision of future daughters among university students.
\end{abstract}

Methods: A cross-sectional study was conducted using a self-administered questionnaire in a random sample of 502 male and female students in Menoufia University between September and December 2017. Bivariate and multivariable logistic regression analyses were performed.

Results: Students were $21.0 \pm 1.6$ years old; 270 (54.0\%) were males, 291 (58.0\%) were non-medical students, and 292 (58.2\%) were rural residents. 204 (46.7\%) students were not aware of the ban and their main source of information about FGM/C was educational curricula or health education sessions (162, 37.0\%). Only 95 (19.0\%) students had good knowledge about FGM/C. 217 (43.3\%) students were neutral towards discontinuing FGM/C. 280 (56.2\%) students disagreed with FGM/C. 296 (59.3\%) students disagreed with circumcision of their future daughters; independent determinants of this outcome were awareness of the ban $(\mathrm{ORa}=1.9)$ and disagreement with: FGM/C preserves females' virginity $(\mathrm{ORa}=5.0)$, has religious basis $(\mathrm{ORa}=3.8)$, makes females happier in marriage $(\mathrm{ORa}=3.5)$, enhances females' hygiene (ORa $=2.1)$.

Conclusions: Knowledge about FGM/C and its ban is low, even in this educated population. FGM/C is still misperceived as a religious percept. Maximizing the utilization of health education and curricula might help increase anti-FGM/C attitudes among university students with neutral perceptions and initiate the much-needed momentum for elimination.

Keywords: Female genital mutilation/cutting, University students, Gender, Knowledge, Perception, Policy, Ban, Egypt

\footnotetext{
* Correspondence: aya.kamaleldin@med.asu.edu.eg

${ }^{1}$ Department of Community, Environmental and Occupational Medicine,

Faculty of Medicine, Ain Shams University, Abbasia Square, PO-box 11566,

Cairo, Egypt

Full list of author information is available at the end of the article
}

(c) The Author(s). 2020 Open Access This article is licensed under a Creative Commons Attribution 4.0 International License, which permits use, sharing, adaptation, distribution and reproduction in any medium or format, as long as you give appropriate credit to the original author(s) and the source, provide a link to the Creative Commons licence, and indicate if changes were made. The images or other third party material in this article are included in the article's Creative Commons licence, unless indicated otherwise in a credit line to the material. If material is not included in the article's Creative Commons licence and your intended use is not permitted by statutory regulation or exceeds the permitted use, you will need to obtain permission directly from the copyright holder. To view a copy of this licence, visit http://creativecommons.org/licenses/by/4.0/. The Creative Commons Public Domain Dedication waiver (http://creativecommons.org/publicdomain/zero/1.0/) applies to the data made available in this article, unless otherwise stated in a credit line to the data. 


\section{Plain English summary}

The United Nations has set a target to eliminate FGM/C by 2030 . FGM/C affects at least 200 million girls and women worldwide. Some studies reported that men also suffer from its consequences. Egypt is one of three countries where half of FGM/C victims live. Despite its complete ban in Egypt since 2008, FGM/C is still practiced. To embark on ending FGM/C in one decade, understanding both male and female youth's perspectives becomes vital in creating a rapid and sustained momentum for elimination.

This study is the first to inform policy on the awareness of this ban and the impact of other interventions among university students and assess FGM/C-related knowledge, perceptions, and determinants of disagreement with FGM/C and circumcision of future daughters. Alarmingly, almost half of the students were not aware of the FGM/C ban. There was a universal lack of good knowledge about FGM/C not only in non-medical, but even in medical students. FGM/C was still misperceived as a religious percept. There was a wide base (43.3\%) of neutral perceptions about FGM/C, which might hinder the progress towards elimination. However, this finding may present itself as an opportunity to intensify targeted engagement and education efforts promoting the abandonment of FGM/C among students with neutral perceptions. Also, this study highlighted opportunities for potential improvement: the main source of students' knowledge about FGM/C was university curricula and health education sessions, therefore, utilizing these potential gateways is crucial to initiate the much-needed momentum for elimination.

\section{Background}

Female genital mutilation/cutting (FGM/C) is a worldwide public health and human rights issue. As an international response, the fifth United Nations' Sustainable Development Goal included a target to eliminate the practice by 2030 [1]. FGM/C refers to traditional practices involving "partial or total excision of the female external genitalia for non-medical purposes" [2]. FGM/C not only results in short- and long-term physical and psychological complications, but leads to death in some girls [2]. Families have been increasingly seeking medical instead of traditional practitioners for their daughters' circumcision to minimize pain and complications, while meeting the cultural demand [3]. The World Health Organization has condemned this 'medicalization' of the practice because it perpetuates FGM/C rather than abolishes it [4].

FGM/C victims live mainly in Africa and Asia [5], and due to immigration, some live in Europe, Australia, the UK and the USA, where FGM/C and its complications have become an issue of growing concern [6, 7]. At least half of the globally estimated 200 million girls and women who have undergone FGM/C live in only three countries: Indonesia, Ethiopia, and Egypt [5]. In Egypt, 92.3\% of ever married women (15-49 years old) and $21.3 \%$ of their daughters (0-19 years old) have been subjected to FGM/C, according to the latest Demographic Health Survey in 2015 [8]. Moreover, 58\% of Egyptian women believed the practice should continue, although this support has declined by $24 \%$ over the last two decades [8]. This is despite Egypt has banned FGM/C in 2008 [9]. There are various reasons for performing FGM/C. In 2008, circumcised Egyptian schoolgirls have reported cleanliness, culture, chastity, and most commonly religious precepts, as reasons that support the continuation of the practice [10]. In 2015, more than half of Egyptian women have similarly reported it on religious basis [8], although several fatwas from religious leaders have been issued to counter these misconceptions in Egypt and in other countries [11].

However, a significant change is unlikely if the ban is implemented in isolation of other interventions (such as health education), considering the deeply rooted public misbeliefs [12, 13]. Also, the extent of awareness of the ban and the impact of other interventions are unknown. Younger generations with higher education would be presumably less supportive of $\mathrm{FGM} / \mathrm{C}$, more likely to have been exposed to such interventions, and would likely lead future change and advocate to break this community norm, but have been scarcely studied in Egypt $[14,15]$ and elsewhere [16-18].

To inform FGM/C prevention policy on the awareness of the FGM/C ban and the impact of other interventions, this study sought to assess and compare medical and non-medical university students' FGM/C-related knowledge, perceptions, and determinants of disagreement with $\mathrm{FGM} / \mathrm{C}$ in general and circumcision of their future daughters in particular.

\section{Methods \\ Study design and setting}

A cross-sectional study was conducted between September and December 2017 in a public university in Menoufia governorate in the Nile Delta of Egypt. Menoufia has urban and rural localities and has the second highest prevalence of $\mathrm{FGM} / \mathrm{C}$ in daughters $0-19$ years old among the Nile Delta governorates [8].

\section{Study sample and sampling procedure}

The target population included male and female university students (approximately 80,000) attending different faculties of Menoufia University. There are 17 faculties in Menoufia University, from which we randomly selected 7 faculties representing medical and non-medical specialties. The selected faculties representing medical specialties included: Medicine, Pharmacy and Nursing, 
while those representing non-medical specialties included: Law, Commerce, Engineering and Science. University students who were in their fourth year of studies (approximately 9700 students) were targeted being the final year of studying for non-medical specialties. A sample size of 493 university students with a sample proportion 1:1 from medical and non-medical students was calculated at a $95 \%$ level of confidence, a study power of $80 \%$, and an alpha error of $5 \%$, under the hypothesis that $28 \%$ of medical students would object to FGM/C abolishment [14] and that proportion would be $10 \%$ higher among non-medical students. Another approximately $2 \%$ of this required sample size $(n=9)$ was added to account for possible non-response and missing data; the target sample was 502 university students.

One trained field interviewer visited each faculty on two alternating days per week for data collection. On the day of data collection, the list of practical classes of fourth year students on that day was obtained, from which one class was randomly selected. Approximately 40 students attended the class in each of the selected faculties. After the class, the field interviewer approached the attending students and asked whether they were interested to participate in the study. Data collection was conducted until the target sample size was achieved.

\section{Study tool and data collection}

After obtaining verbal consent, participants filled an anonymous self-administrated structured questionnaire in Arabic language that took approximately $15 \mathrm{~min}$ to complete. The questionnaire items were adapted from previous literature $[8,14]$ and were pretested on $40 \mathrm{stu}-$ dents from Faculties of Medicine and Science for clarity of the questions and the answer categories; pretest data are not included in this analysis. The questionnaire consisted of three sections:

1- Socio-demographic characteristics: age, gender, rural/urban residence, parents' educational attainment, and faculty.

2- Students' knowledge about FGM/C (4 questions): whether they have any information about FGM/C (yes/no); the main source of their information about FGM/C (family/mass media/educational curricula studied in the university/ health education seminars/other); the purpose of practicing FGM/C (more than one answer option was allowed: traditions/religious/medical/cosmetic/hygienic/ facilitation of easy delivery in the future/male sexual satisfaction/assurance of virginity); and whether they were aware of any legislation that bans FGM/C in Egypt (yes/no).

3- Students' perception regarding FGM/C (12 items): students answered a 5-likert scale for each item whether they: "strongly agree" (1), "agree" (2), "neutral" (3), "disagree" (4), "strongly disagree" (5) with: acceptance of the FGM/C practice; females should perform FGM/C before marriage; FGM/C should be banned from media discussions; the television is unimportant in preventing FGM/C; FGM/C has religious basis; females are indecent until they are circumcised; circumcised females are happier in their marital lives; females cannot please their husbands if uncircumcised; FGM/C enhances females' personal hygiene; FGM/C preserves females' virginity; circumcised females are more respected by the community; and my future daughters should be circumcised.

\section{Statistical analysis}

Serial identification numbers were assigned to each anonymously filled questionnaire. Data were analysed using SPSS (Statistical Package for the Social Sciences, version 25, SSPS Inc., Chicago, IL, USA). Correct knowledge was considered if the student answered "yes" to the (yes/no) knowledge questions, answered "educational curricula" or "health education" or "mass media" to the source of knowledge question, and "traditions" or "medical" to the purpose of FGM/C question. For each correct answer, the participant was assigned a score of 1 and otherwise 0 . Positive perception (favourable response towards discontinuation of $\mathrm{FGM} / \mathrm{C}$ ) was considered if the participant responded "disagree" or "strongly disagree" to the 12 perception items. For each participant, a total knowledge and perception percentage score was calculated. Then, mean percentage scores were calculated and categorized into $<50 \%, 50-75$, and $>75 \%$, representing "poor", "average", and "good" knowledge, or "negative", "neutral", and "positive" perception. Descriptive statistics were performed and presented as frequency and percentages for qualitative variables or mean and standard deviation for quantitative variables. Bivariate analyses were performed using the Chi-squared test or the Independent Samples T-test. Multivariable logistic regression analyses were used to identify the factors associated with disagreement with the practice of FGM/C and circumcision of future daughters among university students, testing the following variables as independent determinants: female gender, urban residence, higher parental education, students of medical faculties, educational curricula or health education as the main source of knowledge about FGM/C, consideration of FGM/C only for a medical purpose, awareness of a legislation that bans FGM/ $\mathrm{C}$, and disagreement with the perception items. Adjusted odds ratios (ORa) and $95 \%$ confidence intervals $(\mathrm{CI})$ are reported. A p-value $\leq 0.05$ was considered statistically significant. 


\section{Ethical considerations}

The Research Ethics Committee, Faculty of Medicine, Ain Shams University, Cairo, Egypt approved this study. Menoufia University provided permission for conduction of the study in its premises. Potential participants were informed about the study objectives and were assured about confidentiality and anonymity of their responses, that their participation was voluntary, and their freedom to withdraw from the study at any time. Students provided consent prior to questionnaire completion.

\section{Results}

\section{Sample characteristics}

A total of 502 university students attending Menoufia University participated in the present study: 211 (42.0\%) from faculties representing medical specialties (Medicine $n=49$, Pharmacy $n=78$, and Nursing $n=84$ ), and 291 (58.0\%) from faculties representing non-medical specialties (Law $n=51$, Commerce $n=117$, Engineering $n=59$, and Science $n=63$ ). The students' mean age was $21.0 \pm$ 1.6 years. More than half of the students were males (270, 54.0\%), and lived in rural areas (292, 58.2\%). Approximately half of the students' mothers $(236,47.1 \%)$ and fathers $(265,53.2 \%)$ had completed secondary or a higher education (Table 1). Sample characteristics of students in the three faculties representing medical specialities as well as the four faculties representing nonmedical specialities are described in Supplementary Table 1.

\section{Knowledge of university students about FGM/C}

Most of the students knew about FGM/C (440, 88.7\%); among whom almost a half $(204,46.7 \%)$ were not aware of legislations that ban FGM/C. The main source of these students' information about FGM/C was the educational curricula they studied at university or health education sessions (162,37.0\%), followed by the family (140, 32.0\%), and mass media (90, 20.5\%). A significantly larger proportion of non-medical than medical students and females than males relied mainly on their family as the main source of information about FGM/C. More than two-thirds of the students $(372,67.9 \%)$ reported that the purpose of conducting FGM/C was traditions, $95(17.3 \%)$ reported it has religious purposes, and 22 (4.0\%) reported it has medical purposes (Tables 1 and 2).

\section{Perception of university students regarding FGM/C}

Overall responses to perception items are presented in Fig. 1. In general, more than a half of the students did not accept the practice of FGM/C $(280,56.2 \%)$ and disagreed with their future daughters being circumcised (296, 59.3\%). More than a half to approximately twothirds of the students disagreed with all the perception items. Approximately two-fifths $(198,39.7 \%)$ disagreed with the item FGM/C has religious basis. Significantly more medical than non-medical students disagreed with the following perception items: females should perform FGM/C before marriage (65.7\% versus $54.7 \%$ ); circumcised females are happier in their marital lives $(63.5 \%$ versus 51.0\%); and females cannot please their husbands if uncircumcised (69.2\% versus 59.0\%). Significantly more males than females disagreed with the items: FGM/C has religious basis (44.7\% versus $35.3 \%)$ and females are indecent until they are circumcised (78.5\% versus $66.9 \%)$. Significantly more females than males disagreed with the following perception items: FMG/C enhances females' personal hygiene (62.6\% versus $49.1 \%)$; FMG/C preserves females' virginity $(66.1 \%$ versus 49.1\%); and my future daughters should be circumcised (65.8\% versus $53.9 \%$ ) (Tables 1 and 2 ).

\section{Mean total percentage scores and levels of knowledge and perception about FGM/C}

Students' mean total percentage scores were below 75 . Approximately one-fifth $(95,19.0 \%)$ of the students had a good level of knowledge. Approximately half of the students $(238,47.5 \%)$ reported positive perception and 217 (43.3\%) reported neutral perception towards discontinuing the practice of $\mathrm{FGM} / \mathrm{C}$. Differences between medical/non-medical students, males/females, urban/ rural residents, and by level of parental education are presented in Table 3.

Determinants of disagreement with the practice of FGM/C and circumcision of future daughters

Of the variables tested in the multivariable logistic regression model, the following were independent determinants of disagreement with the practice of $\mathrm{FGM} / \mathrm{C}$ : urban residence $(\mathrm{ORa}=3.6,95 \% \mathrm{CI}: 1.9-6.7)$, and disagreement with the following perception items: 'FGM/C has religious basis' (ORa $=6.3,95 \% \mathrm{CI}: 3.3-12.0)$, 'FMG/C preserves females' virginity' ( $\mathrm{ORa}=3.8,95 \% \mathrm{CI}: 1.9-7.7)$, 'circumcised females are happier in their marital lives' $(\mathrm{ORa}=3.7,95 \% \mathrm{CI}: 1.9-7.2)$, 'females are indecent until they are circumcised' $(\mathrm{ORa}=2.5,95 \% \mathrm{CI}: 1.2-5.4)$, and 'the television is unimportant in preventing $\mathrm{FGM} / \mathrm{C}$ ' $(\mathrm{ORa}=2.1,95 \% \mathrm{CI}: 1.1-3.8)$. The following variables were independent determinants of disagreement with circumcision of future daughters: awareness of a legislation that bans FGM/C (ORa $=1.9,95 \% \mathrm{CI}: 1.1-3.4)$, and disagreement with the following perception items: 'FMG/C preserves females' virginity' $(\mathrm{ORa}=5.0$, 95\%CI:2.5-9.9), 'FGM/C has religious basis' (ORa = 3.8, 95\%CI:1.9-7.6), 'circumcised females are happier in their marital lives' (ORa $=3.5,95 \% \mathrm{CI}: 1.8-6.9)$, 'FMG/C enhances females' personal hygiene' (ORa = 2.1, 95\%CI:1.1-4.4), and 'the television is unimportant in preventing $\mathrm{FGM} / \mathrm{C}^{\prime} \quad(\mathrm{ORa}=2.1, \quad 95 \% \mathrm{CI}: 1.2-3.9)$ 
Table 1 Sample characteristics, knowledge and perceptions about FGM/C among medical and non-medical university students $(n=502)$

\begin{tabular}{|c|c|c|c|c|c|c|c|c|}
\hline & \multicolumn{2}{|l|}{ Total $^{\mathbf{a}}$} & \multicolumn{2}{|c|}{ Non-medical } & \multicolumn{2}{|l|}{ Medical } & \multirow[t]{2}{*}{$x^{2}$} & \multirow[t]{2}{*}{$p$-value } \\
\hline & $N=502$ & $\%$ & $N=291$ & $\%$ & $N=211$ & $\%$ & & \\
\hline Gender, male & 270 & 54.0 & 164 & 56.6 & 106 & 50.5 & 1.810 & 0.203 \\
\hline Residence, rural & 292 & 58.2 & 167 & 57.4 & 125 & 59.2 & 0.173 & 0.714 \\
\hline \multicolumn{9}{|l|}{ Mother's education } \\
\hline Secondary complete/higher & 236 & 47.1 & 126 & 43.4 & 110 & 52.1 & 5.327 & 0.070 \\
\hline Primary complete/some secondary & 201 & 40.1 & 120 & 41.4 & 81 & 38.4 & & \\
\hline No education/some primary & 64 & 12.8 & 44 & 15.2 & 20 & 9.5 & & \\
\hline \multicolumn{9}{|l|}{ Father's education } \\
\hline Secondary complete/higher & 265 & 53.2 & 146 & 50.5 & 119 & 56.9 & 5.485 & 0.064 \\
\hline Primary complete/some secondary & 209 & 42.0 & 124 & 42.9 & 85 & 40.7 & & \\
\hline No education/some primary & 24 & 4.8 & 19 & 6.6 & 5 & 2.4 & & \\
\hline Knows about FGM/C, yes & 440 & 88.7 & 247 & 86.7 & 193 & 91.5 & 2.792 & 0.114 \\
\hline Aware of any legislation that bans FGM/C, yes & 204 & 46.7 & 111 & 45.1 & 93 & 48.7 & 0.55 & 0.499 \\
\hline \multicolumn{9}{|l|}{ Source of knowledge about FGM/C } \\
\hline Family & 140 & 32.0 & 91 & 37.0 & 49 & 25.5 & 8.714 & 0.033 \\
\hline Educational curricula/health education & 162 & 37.0 & 89 & 36.2 & 73 & 38.0 & & \\
\hline Mass media & 90 & 20.5 & 41 & 16.7 & 49 & 25.5 & & \\
\hline Other & 46 & 10.5 & 25 & 10.2 & 21 & 10.9 & & \\
\hline \multicolumn{9}{|l|}{ Purpose of conducting $\mathrm{FGM} / \mathrm{C}^{\mathrm{b}}$} \\
\hline Traditions & 372 & 67.9 & 200 & 64.5 & 172 & 72.3 & 7.468 & 0.058 \\
\hline Religious & 95 & 17.3 & 52 & 16.8 & 43 & 18.1 & & \\
\hline Medical & 22 & 4.0 & 15 & 4.8 & 7 & 2.9 & & \\
\hline Other & 59 & 10.8 & 43 & 13.9 & 16 & 6.7 & & \\
\hline \multicolumn{9}{|l|}{ Disagree with perception items: } \\
\hline Acceptance of the $\mathrm{FGM} / \mathrm{C}$ practice & 280 & 56.2 & 151 & 52.6 & 129 & 61.1 & 3.590 & 0.068 \\
\hline Females should be circumcised before marriage & 296 & 59.3 & 158 & 54.7 & 138 & 65.7 & 6.146 & 0.016 \\
\hline FGM/C should be banned from media discussions & 337 & 67.8 & 188 & 65.5 & 149 & 71.0 & 1.648 & 0.208 \\
\hline The television is unimportant in preventing FGM/C & 324 & 65.1 & 184 & 63.9 & 140 & 66.7 & 0.412 & 0.568 \\
\hline FGM/C has religious basis & 198 & 39.7 & 106 & 36.6 & 92 & 44.0 & 2.830 & 0.096 \\
\hline Females are indecent until they are circumcised & 361 & 72.3 & 202 & 69.7 & 159 & 76.1 & 2.503 & 0.128 \\
\hline Circumcised females are happier in their marital lives & 280 & 56.2 & 148 & 51.0 & 132 & 63.5 & 7.600 & 0.006 \\
\hline Females cannot please their husbands if uncircumcised & 315 & 63.3 & 171 & 59.0 & 144 & 69.2 & 5.491 & 0.024 \\
\hline FMG/C enhances females' personal hygiene & 276 & 55.4 & 157 & 54.1 & 119 & 57.2 & 0.463 & 0.523 \\
\hline FMG/C preserves females' virginity & 283 & 56.8 & 157 & 54.1 & 126 & 60.6 & 2.047 & 0.169 \\
\hline Circumcised females are more respected by community & 338 & 67.7 & 192 & 66.2 & 146 & 69.9 & 0.740 & 0.438 \\
\hline My future daughters should be circumcised & 296 & 59.3 & 163 & 56.2 & 133 & 63.3 & 2.778 & 0.098 \\
\hline
\end{tabular}

FGM/C Female genital mutilation/cutting

${ }^{\text {a }}$ Some variables had missing values

${ }^{b}$ More than one answer option was allowed

${ }^{c}$ Chi-squared test

(Table 4). The perception item 'females should be circumcised before marriage' was not included in the multivariable model because it showed high correlation with the dependent variables.

\section{Discussion}

Approximately half (46.7\%) of the university students in this study were not aware of the ban on FGM/C in Egypt. This alarming finding reflects the failure of 
Table 2 Sample characteristics, knowledge and perceptions about FGM/C among male and female university students $(n=502)$

\begin{tabular}{|c|c|c|c|c|c|c|c|c|}
\hline & Total $^{\mathbf{a}}$ & & Males & & Females & & $x^{2}$ & $\boldsymbol{p}$-value \\
\hline & $N=500$ & $\%$ & $N=270$ & $\%$ & $N=230$ & $\%$ & & \\
\hline Faculty, non-medical & 290 & 58.0 & 164 & 60.7 & 126 & 54.8 & 1.810 & 0.203 \\
\hline Residence, rural & 290 & 58.0 & 156 & 57.8 & 134 & 58.3 & 0.012 & 0.928 \\
\hline Mother's education & & & & & & & & \\
\hline Secondary complete/higher & 236 & 47.3 & 131 & 48.7 & 105 & 45.7 & 1.768 & 0.413 \\
\hline Primary complete/some secondary & 200 & 40.1 & 101 & 37.5 & 99 & 43.0 & & \\
\hline No education/some primary & 63 & 12.6 & 37 & 13.8 & 26 & 11.3 & & \\
\hline Father's education & & & & & & & & \\
\hline Secondary complete/higher & 264 & 53.2 & 135 & 50.4 & 129 & 56.6 & 2.484 & 0.289 \\
\hline Primary complete/some secondary & 208 & 41.9 & 121 & 45.1 & 87 & 38.2 & & \\
\hline No education/some primary & 24 & 4.8 & 12 & 4.5 & 12 & 5.3 & & \\
\hline Knows about FGM/C, yes & 438 & 88.7 & 237 & 88.8 & 201 & 88.5 & 0.006 & 1.000 \\
\hline Aware of any legislation that bans FGM/C, yes & 202 & 46.4 & 105 & 44.5 & 97 & 48.7 & 0.785 & 0.387 \\
\hline Source of knowledge about FGM/C & & & & & & & & \\
\hline Family & 139 & 31.9 & 61 & 25.8 & 78 & 39.0 & 9.779 & 0.021 \\
\hline Educational curricula/health education & 161 & 36.9 & 64 & 32.0 & 97 & 41.1 & & \\
\hline Mass media & 90 & 20.6 & 49 & 20.8 & 41 & 20.5 & & \\
\hline Other & 46 & 10.6 & 29 & 12.3 & 17 & 8.5 & & \\
\hline Purpose of conducting $\mathrm{FGM} / \mathrm{C}^{\mathrm{b}}$ & & & & & & & & \\
\hline Traditions & 353 & 64.8 & 191 & 65.0 & 180 & 71.7 & 3.247 & 0.355 \\
\hline Religious & 94 & 17.2 & 53 & 18.0 & 41 & 16.3 & & \\
\hline Medical & 21 & 3.9 & 14 & 4.8 & 7 & 2.8 & & \\
\hline Other & 59 & 10.8 & 36 & 12.2 & 23 & 9.2 & & \\
\hline Disagree with perception items: & & & & & & & & \\
\hline Acceptance of the $\mathrm{FGM} / \mathrm{C}$ practice & 279 & 56.3 & 141 & 52.4 & 138 & 60.8 & 3.510 & 0.069 \\
\hline Females should be circumcised before marriage & 295 & 59.4 & 153 & 56.9 & 142 & 62.3 & 1.493 & 0.234 \\
\hline FGM/C should be banned from media discussions & 336 & 67.9 & 180 & 67.4 & 156 & 68.4 & 0.057 & 0.847 \\
\hline The television is unimportant in preventing FGM/C & 323 & 65.1 & 168 & 62.7 & 155 & 68.0 & 1.521 & 0.221 \\
\hline FGM/C has religious basis & 197 & 39.6 & 102 & 44.7 & 95 & 35.3 & 4.578 & 0.035 \\
\hline Females are indecent until they are circumcised & 359 & 72.2 & 179 & 78.5 & 180 & 66.9 & 8.271 & 0.005 \\
\hline Circumcised females are happier in their marital lives & 278 & 56.0 & 140 & 52.0 & 138 & 60.8 & 3.825 & 0.057 \\
\hline Females cannot please their husbands if uncircumcised & 313 & 63.1 & 154 & 67.8 & 159 & 59.1 & 4.033 & 0.050 \\
\hline FMG/C enhances females' personal hygiene & 274 & 55.2 & 132 & 49.1 & 142 & 62.6 & 9.054 & 0.003 \\
\hline FMG/C preserves females' virginity & 282 & 56.9 & 132 & 49.1 & 150 & 66.1 & 14.519 & $<0.001$ \\
\hline Circumcised females are more respected by community & 336 & 67.6 & 172 & 63.9 & 164 & 71.9 & 3.597 & 0.068 \\
\hline My future daughters should be circumcised & 295 & 59.4 & 145 & 53.9 & 150 & 65.8 & 7.227 & 0.008 \\
\hline
\end{tabular}

FGM/C Female genital mutilation/cutting

a Some variables had missing values

${ }^{b}$ More than one answer option was allowed

c Chi-squared test

awareness raising campaigns in communicating a fundamental milestone in combating the practice. We could not find any published results of studies that have directly investigated the awareness of the ban, yet this is an integral message that should be incorporated in future efforts to support the abolishment of FGM/C. Only a fifth (19.0\%) of the students had good knowledge about FGM/C. This proportion was significantly higher among medical (25.6\%) than non-medical students (14.6\%), but the difference was small. This finding suggests that lack of knowledge is general. However, students' main source of information about FGM/C was educational curricula 


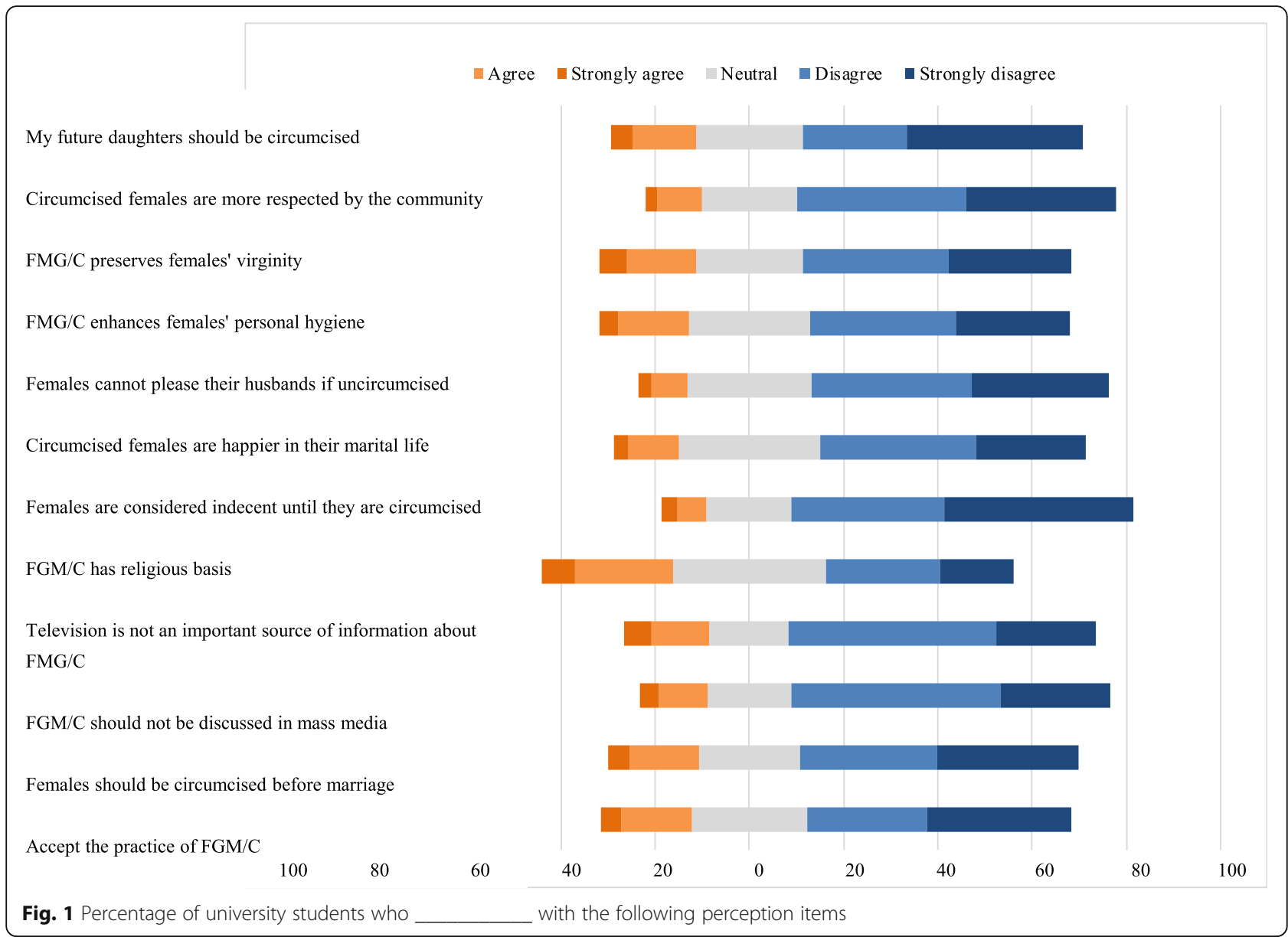

or health education sessions (37.0\%). Investing in research that informs on the best approaches for maximizing the utilization of university educational curricula and health education sessions as potential gateways to universal exposure to knowledge about FGM/C is crucial to initiate the much-needed momentum for elimination of $\mathrm{FGM} / \mathrm{C}$.

While more than half of the students disagreed with FGM/C (56.2\%) and with their future daughters being circumcised (59.3\%), a considerable proportion (43.3\%) of students were neutral about discontinuing FGM/C. This is another interesting finding; neutral perceptions about FGM/C do not only form a challenge that may weaken and delay the overall progress towards elimination, they are unacceptable from human rights and public health perspectives. Formulating messages that convey the worldwide documented complications of the procedure and resultant mortalities among girls and women [2] can significantly affect this wide base of neutral perceptions. This finding may present itself as a golden opportunity to intensify targeted engagement and education efforts promoting the abandonment of FGM/C. The proportion agreeing with the practice has decreased by only $10 \%$ from a similar local study conducted two decades earlier [14]. Also, there has been only a modest observed reduction in prevalence of and attitudes about FGM/C comparing the situation before and after the ban $[9,19]$. Interventions regarding FGM/C have been sporadic; the evaluation of their impact has not been systematically documented $[12,20]$. Few local studies in Upper Egypt have indirectly investigated the impact of the FGM/ $\mathrm{C}$ ban. Rasheed et al. reported that the annual incidence of FGM/C in the 2 years post- implementation of the ban was still 'very high' (7\%) among girls and young women [21]. The authors also report that $34.4 \%$ of young physicians approved the practice; a proportion similar to that found among medical students in the present study (38.4\%). Hassanin et al. examined the prevalence of FGM/ $\mathrm{C}$ among girls after 6 years of implementation of the ban and found that the practice is high and the authors called for revising public awareness and changing attitudes [22]. This modest change in prevalence despite the implementation may be explained by our finding that only 1 in 5 students had good knowledge about FGM/C. Therefore, implementation of the ban in isolation of other interventions is not expected to bring about the rapid and 
Table 3 Mean total percentage scores and levels of knowledge and perception about FGM/C among university students ( $n=502$ )

\begin{tabular}{|c|c|c|c|c|c|c|c|c|c|}
\hline \multirow[b]{2}{*}{ Characteristic } & \multirow[b]{2}{*}{$N^{a}$} & \multirow{2}{*}{$\begin{array}{l}\text { Mean total percentage } \\
\text { score of knowledge } \\
\text { mean (SD) }\end{array}$} & \multirow{2}{*}{$\begin{array}{l}\text { Mean total percentage } \\
\text { score of perception } \\
\text { mean (SD) }\end{array}$} & \multicolumn{3}{|c|}{ Level of knowledge $n(\%)$} & \multicolumn{3}{|c|}{ Level of perception $\mathrm{n}(\%)$} \\
\hline & & & & Poor & Average & Good & Negative & Neutral & Positive \\
\hline Total & 501 & $66.3(23.9)$ & $72.9(16.2)$ & 68 (13.6) & $338(67.5)$ & $95(19.0)$ & $46(9.2)$ & $217(43.3)$ & $238(47.5)$ \\
\hline \multicolumn{10}{|l|}{ Faculty } \\
\hline Non-medical & 290 & $63.2(23.9)$ & $71.6(15.3)$ & 48 (16.6) & $201(69.3)$ & $41(14.1)$ & $25(8.6)$ & $142(49.0)$ & $123(42.4)$ \\
\hline Medical & 211 & $70.5(23.1)$ & $74.7(17.3)$ & $20(9.5)$ & $137(64.5)$ & $54(25.6)$ & $21(10.0)$ & $75(35.5)$ & $115(54.5)$ \\
\hline Statistic $^{b}$ & & 2.109 & 3.041 & 13.300 & & & 9.072 & & \\
\hline$p$-value & & 0.001 & 0.032 & 0.001 & & & 0.011 & & \\
\hline \multicolumn{10}{|l|}{ Gender } \\
\hline Males & 270 & $65.9(24.9)$ & $70.8(15.8)$ & $43(15.9)$ & $171(63.3)$ & $56(20.7)$ & $26(9.6)$ & $136(50.4)$ & $108(40.0)$ \\
\hline Females & 229 & $66.5(22.5)$ & $75.4(16.4)$ & $25(10.9)$ & $166(72.5)$ & $38(16.6)$ & $20(8.7)$ & $80(34.9)$ & $129(56.3)$ \\
\hline Statistic $^{b}$ & & 4.617 & 0.207 & 4.950 & & & 13.887 & & \\
\hline$p$-value & & 0.795 & 0.002 & 0.084 & & & 0.001 & & \\
\hline \multicolumn{10}{|l|}{ Residence } \\
\hline Rural & 292 & $65.3(23.7)$ & 70.7 (16.9) & $40(13.7)$ & $202(69.2)$ & $50(17.1)$ & $37(12.7)$ & $131(44.9)$ & $124(42.5)$ \\
\hline Urban & 209 & $67.9(24.1)$ & $75.9(14.7)$ & $28(13.4)$ & $136(65.1)$ & $45(21.5)$ & $9(4.3)$ & $86(41.1)$ & $114(54.5)$ \\
\hline Statistic $^{b}$ & & 0.008 & 6.906 & 1.561 & & & 13.413 & & \\
\hline$p$-value & & 0.297 & $<0.001$ & 0.458 & & & 0.001 & & \\
\hline \multicolumn{10}{|l|}{ Mother's education } \\
\hline $\begin{array}{l}\text { Completed secondary or } \\
\text { higher }\end{array}$ & 235 & $69.7(23.5)$ & $74.9(16.4)$ & $24(10.2)$ & $155(66.0)$ & $56(23.8)$ & $19(8.1)$ & $89(37.9)$ & $127(54.0)$ \\
\hline Other & 265 & $63.5(23.5)$ & $71.2(15.9)$ & $43(16.2)$ & $183(69.1)$ & $39(14.7)$ & $27(10.2)$ & $127(47.9)$ & $111(41.9)$ \\
\hline Statistic ${ }^{b}$ & & 1.226 & 0.268 & 8.982 & & & 7.379 & & \\
\hline$p$-value & & 0.003 & 0.010 & 0.011 & & & 0.025 & & \\
\hline \multicolumn{10}{|l|}{ Father's education } \\
\hline $\begin{array}{l}\text { Completed secondary or } \\
\text { higher }\end{array}$ & 265 & $68.2(24.3)$ & $74.4(16.9)$ & $31(11.7)$ & $173(65.3)$ & $61(23.0)$ & $21(7.9)$ & $106(40.0)$ & $138(52.1)$ \\
\hline Other & 232 & $63.7(23.2)$ & $71.3(15.4)$ & $37(15.9)$ & $163(70.3)$ & $32(13.8)$ & $25(10.8)$ & $109(47.0)$ & $98(42.2)$ \\
\hline Statistic $^{b}$ & & 0.017 & 3.778 & 7.713 & & & 5.000 & & \\
\hline$p$-value & & 0.035 & 0.032 & 0.021 & & & 0.082 & & \\
\hline
\end{tabular}

FGM/C Female genital mutilation/cutting

a Some variables had missing values

${ }^{b} \mathrm{~F}$ statistic for Independent Samples t-test and $\mathrm{X}^{2}$ statistic for Chi-squared test

necessary change to achieve FGM/C elimination. The role of television as a media channel in preventing FGM/C was an independent determinant of circumcision of future daughters in the present study. Media coverage, including social media, is important in shifting adolescent girls' perceptions positively towards discontinuation of FGM/C in Egypt and other African countries [13, 23].

Gender differences in knowledge about FGM/C were not obvious in this sample of university students. This highlights the importance of investing not only in female but also in male education about FGM/C, because men are also affected by its complications; the issue no longer pertains to women alone [24]. Men may play a key role in advocacy as husbands, religious, and community leaders to dismantle the myths about 'FGM/C makes females happier in their marital lives' or 'FGM/C has religious basis' that were independent determinants of circumcision of future daughters in the present study. Mothers were reported as the main decision-makers for circumcision of their daughters [10]. This may be because half of the women interviewed in the latest Egyptian Demographic Health Survey believed that men prefer the practice to continue [8]; while in fact, recent evidence from Egypt [25] and from some African countries [5] suggests men oppose the practice even more than women. Therefore, men's collaboration with women in community programs may help initiate a societal dialogue about their actual preferences and roles in this decision. 
Table 4 Factors associated with disagreement with the practice of FGM/C and circumcision of future daughters among university students $(n=502)$

\begin{tabular}{|c|c|c|c|c|c|c|c|c|}
\hline \multirow{2}{*}{ Characteristic } & \multicolumn{4}{|c|}{ Disagree with the practice of FGM/C } & \multicolumn{4}{|c|}{ Disagree with circumcision of future daughters } \\
\hline & $\begin{array}{l}\text { Unadjusted } \\
\mathrm{OR}^{\mathbf{a}}(95 \% \mathrm{Cl})\end{array}$ & $\boldsymbol{p}$-value & $\begin{array}{l}\text { Adjusted } \\
\mathrm{OR}^{\mathbf{b}}(95 \% \\
\mathrm{Cl})\end{array}$ & $p$-value & $\begin{array}{l}\text { Unadjusted } \\
\mathrm{OR}^{\mathbf{a}}(95 \% \mathrm{Cl})\end{array}$ & $\boldsymbol{p}$-value & $\begin{array}{l}\text { Adjusted } \\
\mathrm{OR}^{\mathbf{b}}(95 \% \\
\mathrm{Cl})\end{array}$ & $p$-value \\
\hline Gender (female vs male) & $1.4(0.9-2.0)$ & 0.069 & $0.9(0.5-1.6)$ & 0.788 & $1.7(1.1-2.4)$ & 0.008 & $1.1(0.6-1.9)$ & 0.737 \\
\hline Residence (urban vs rural) & $2.1(1.5-3.1)$ & $<0.001$ & $3.6(1.9-6.7)$ & $<0.001$ & $1.5(1.1-2.2)$ & 0.027 & $1.8(0.9-3.3)$ & 0.051 \\
\hline $\begin{array}{l}\text { Mother education (completed secondary or } \\
\text { higher vs other) }\end{array}$ & $1.4(0.9-1.9)$ & 0.086 & $1.2(0.6-2.3)$ & 0.581 & $1.9(1.3-2.7)$ & 0.001 & $1.8(0.9-3.4)$ & 0.126 \\
\hline $\begin{array}{l}\text { Father education (completed secondary or higher } \\
\text { vs other) }\end{array}$ & $1.2(0.9-1.7)$ & 0.317 & $0.7(0.4-1.4)$ & 0.328 & $1.5(1.1-2.2)$ & 0.022 & $1.1(0.6-2.3)$ & 0.707 \\
\hline Faculty (medical vs non-medical) & $1.4(0.9-2.0)$ & 0.068 & $1.2(0.7-2.0)$ & 0.575 & $1.4(0.9-1.9)$ & 0.098 & $1.1(0.6-1.9)$ & 0.765 \\
\hline $\begin{array}{l}\text { Main source of knowledge about FGM/C } \\
\text { (educational curricula/health education vs other) }\end{array}$ & $1.3(0.9-1.9)$ & 0.206 & $1.4(0.8-2.5)$ & 0.257 & $1.0(0.7-1.5)$ & 1.000 & $0.8(0.4-1.4)$ & 0.358 \\
\hline $\begin{array}{l}\text { Main purpose of FGM/C } \\
\text { (only medical purpose vs other) }\end{array}$ & $0.9(0.4-2.2)$ & 1.000 & $1.6(0.5-5.3)$ & 0.461 & $0.5(0.2-1.1)$ & 0.079 & $0.4(0.1-1.5)$ & 0.184 \\
\hline $\begin{array}{l}\text { Aware of a legislation that bans FGM/C } \\
\text { (yes vs no) }\end{array}$ & $1.5(1.1-2.2)$ & 0.023 & $0.8(0.5-1.5)$ & 0.550 & $2.4(1.6-3.5)$ & $<0.001$ & $1.9(1.1-3.4)$ & 0.029 \\
\hline \multicolumn{9}{|c|}{ Disagrees with the following perception items (vs agrees): } \\
\hline $\begin{array}{l}\text { FGM/C should be banned from media } \\
\text { discussions }\end{array}$ & $2.3(1.6-3.3)$ & $<0.001$ & $1.0(0.5-1.9)$ & 0.963 & $2.2(1.5-3.3)$ & $<0.001$ & $0.8(0.4-1.5)$ & 0.498 \\
\hline $\begin{array}{l}\text { The television is unimportant in preventing } \\
\mathrm{FGM} / \mathrm{C}\end{array}$ & $4.4(2.9-6.6)$ & $<0.001$ & $2.1(1.1-3.8)$ & 0.017 & $4.8(3.3-7.2)$ & $<0.001$ & $2.1(1.2-3.9)$ & 0.014 \\
\hline FGM/C has religious basis & $9.3(5.9-14.6)$ & $<0.001$ & $\begin{array}{l}6.3(3.3- \\
12.0)\end{array}$ & $<0.001$ & $7.5(4.8-11.8)$ & $<0.001$ & $3.8(1.9-7.6)$ & $<0.0$ \\
\hline Females are indecent until they are circumcised & $6.2(3.9-9.7)$ & $<0.001$ & $2.5(1.2-5.4)$ & 0.019 & $6.3(4.0-9.7)$ & $<0.001$ & $1.8(0.9-3.7)$ & 0.115 \\
\hline $\begin{array}{l}\text { Circumcised females are happier in their marital } \\
\text { lives }\end{array}$ & $10.9(7.2-16.6)$ & $<0.001$ & $3.7(1.9-7.2)$ & $<0.001$ & $10.8(7.1-16.5)$ & $<0.001$ & $3.5(1.8-6.9)$ & $<0.001$ \\
\hline $\begin{array}{l}\text { Females cannot please their husbands if } \\
\text { uncircumcised }\end{array}$ & $4.3(2.9-6.4)$ & $<0.001$ & $0.7(0.3-1.3)$ & 0.243 & $3.9(2.6-5.7)$ & $<0.001$ & $0.6(0.3-1.2)$ & 0.146 \\
\hline FMG/C enhances females' personal hygiene & $9.5(6.3-14.4)$ & $<0.001$ & $1.7(0.9-3.3)$ & 0.099 & $11.5(7.5-17.6)$ & $<0.001$ & $2.1(1.1-4.1)$ & 0.025 \\
\hline FMG/C preserves females' virginity & $14.1(9.4-21.9)$ & $<0.001$ & $3.8(1.9-7.7)$ & $<0.001$ & $18.0(11.5-28.4)$ & $<0.001$ & $5.0(2.5-9.9)$ & $<0.001$ \\
\hline Circumcised females are more respected by & $5.1(3.4-7.6)$ & $<0.001$ & $0.7(0.4-1.5)$ & 0.388 & $6.2(4.1-9.4)$ & $<0.001$ & $0.9(0.5-1.9)$ & 0.914 \\
\hline
\end{tabular}
community

FGM/C Female genital mutilation/cutting, OR Odds ratio, $\mathrm{Cl}$ confidence interval

${ }^{a}$ Chi-squared test

${ }^{\mathrm{b}}$ Multivariable logistic regression

The level of knowledge about FGM/C in the present study was significantly higher among students with higher parental education. Higher parental education was negatively associated with the prevalence of FGM/C among schoolgirls [10]. Also, the prevalence of FGM/C among daughters of mothers who completed secondary/higher education is half that among daughters of mothers who only completed primary/some secondary education [8]. Positive perceptions towards the discontinuation of FGM/ $\mathrm{C}$ were significantly higher in females, urban residents, and students with higher parental education, as similarly reported in previous studies $[8,17,18]$.

\section{Strengths and limitations}

This study sought to understand university students' views about FGM/C. Although important, to our knowledge, this subpopulation's views have been scarcely studied globally and locally [14-18]. A considerable number (2.7 million) of school graduates continued studies in public universities in Egypt in 2017 and this number is likely to increase [26]. University students will presumably have leading and influential roles in the community. The dynamic engagement of youth in this issue is vital, specifically in a country where $\mathrm{FGM} / \mathrm{C}$ has been banned more than a decade ago, however, a wide gap exists between the aspired and the actual impact of the ban and the other anti-FGM/C interventions on the FGM/C prevalence trends. Also, we have included males and non-medical individuals; relevant views of these subpopulations have been scarcely studied, although they form a majority in the Egyptian society. Furthermore, this may be the first study to assess the awareness of the ban. However, the 
study sample may not accurately represent the wider views of private and public university students or the general population in Egypt and the cross-sectional design may not allow causal inferences. Random sampling was used to minimize sampling bias. The self-administered method had several advantages considering the sensitivity of the topic: First, it minimized social desirability bias in respondents' answers that may have resulted from face-to-face interviews. Second, it reduced the possibility of selection bias, where students with specific views about FGM/C may have systematically refused to participate if we have used face-toface interviews. Third, it diminished interviewer bias; students were given their own space to freely answer the questions without interference or being affected by the gender of the interviewer. No questions about personal experiences of FGM/C were included and we cannot assess how this may have affected female students' responses; we noted in the pretest the students' busy schedule and the minimal time they had between classes, therefore, we designed the questionnaire to be simple, short and non-invasive as much as possible to ensure complete and honest responses. Also, the knowledge items in the questionnaire did not cover knowledge about psychological or physical complications to the girl or the mother, such as anxiety, pain, bleeding, mortality, etc. Thus, these items may need to be addressed in future studies. Furthermore, the target sample size has been achieved and we have taken into account nonresponse and missing values (another $2 \%$ was added to the calculated sample based on the pretest results), thus the minimal missing data and possible differences between responders and nonresponders have unlikely biased our findings.

\section{Conclusions}

Understanding youth's knowledge and perceptions about $\mathrm{FGM} / \mathrm{C}$ in general and in future daughters in particular was an essential first step that provided insight into the factors that might be hindering the impact of the antiFGM/C interventions, such as the insufficient knowledge about FGM/C and its ban, and the persistent misperception about $\mathrm{FGM} / \mathrm{C}$ as a religious percept. Also, this study highlighted opportunities for potential improvement, such as maximizing the use of university curricula and health education sessions - as the main source of knowledge about FGM/C among university students - to increase the anti-FGM/C attitudes among students with neutral perceptions about the practice.

\section{Supplementary information}

Supplementary information accompanies this paper at https://doi.org/10. 1186/s12978-020-00941-8.

Additional file 1: Supplementary Table 1. Participant characteristics by faculty.

\section{Abbreviations}

FGM/C: Female genital mutilation/cutting; ORa: Adjusted odds ratios; Cl: 95\% confidence intervals; UK: United Kingdom; USA: United States of America

\section{Acknowledgements}

Not applicable.

\section{Authors' contributions}

AM participated in the study design, advised on the study tools and data management, supervised the study conduction, conducted statistical data analysis, prepared the tables and figures, interpreted the data, performed literature search, and wrote the manuscript. SAG Collected data for the study and performed literature search. GEA conceptualized the study, participated in the study design, advised on the study tools, and supervised the study conduction. All authors critically reviewed the manuscript and approved the final version for submission.

\section{Funding}

None.

Availability of data and materials

All data generated or analysed during this study are included in this published article.

Ethics approval and consent to participate

The Research Ethics Committee, Faculty of Medicine, Ain Shams University, Cairo, Egypt (FWA 000017585) approved this study. All students provided consent to participate prior to questionnaire completion.

Consent for publication

Not applicable.

\section{Competing interests}

The authors declare that they have no competing interests.

\section{Author details}

'Department of Community, Environmental and Occupational Medicine, Faculty of Medicine, Ain Shams University, Abbasia Square, PO-box 11566, Cairo, Egypt. ${ }^{2}$ Family Medicine Unit, Menoufia, Egypt.

Received: 11 March 2020 Accepted: 3 June 2020

Published online: 10 June 2020

\section{References}

1. United Nations. Sustainable development goals knowledge platform. Sustainable development goal 5. Achieve gender equality and empower all women and girls. Targets \& indicators. 2016. https:// sustainabledevelopment.un.org/sdg5; 2016.Accessed 15 Feb 2020.

2. World Health Organization. Guidelines on the Management of Health Complications from Female Genital Mutilation. Geneva: CHE; 2016. https:// www.who.int/reproductivehealth/topics/fgm/management-healthcomplications-fgm/en/; 2016.Accessed 15 Feb 2020.

3. Leye E, Van Eekert N, Shamu S, Esho T, Barrett H, ANSER. Debating medicalization of Female Genital Mutilation/Cutting (FGM/C): learning from (policy) experiences across countries. Reprod Health. 2019;16(1):158. https:// doi.org/10.1186/s12978-019-0817-3.

4. World Health Organization. Global strategy to stop health-care providers from performing female genital mutilation. 2010. https://apps.who.int/iris/ bitstream/handle/10665/70264/WHO_RHR_10.9_eng.pdf;jsessionid=0EA813 8C82373435B8BA29353EA7F68B? sequence=1; 2010. Accessed 15 Feb 2020.

5. United Nations Children's Fund, Female Genital Mutilation/Cutting: A global concern, UNICEF, New York, 2016, http://data.unicef.org/resources/femalegenital-mutilation-cutting-a-global-concern.html; 2016. Accessed 15 Feb 2020.

6. Dawson A, Rashid A, Shuib R, Wickramage K, Budiharsana M, Hidayana IM, et al. Addressing female genital mutilation in the Asia Pacific: the neglected sustainable development target. Aust N Z J Public Health. 2020;44(1):8-10. https://doi.org/10.1111/1753-6405.12956.

7. Rymer J. Female genital mutilation: everyone's problem. British J of Gen Prac. 2013:515-6. https://doi.org/10.3399/bjgp13X673586. 
8. Ministry of Health and Population [Egypt], El-Zanaty and Associates [Egypt], and ICF International.2015. Egypt Demographic and Health Survey. Cairo and Rockville: Ministry of Health and Population and ICF International; 2014.

9. Hassanin IM, Shaaban OM. Impact of the complete ban on female genital cutting on the attitude of educated women from upper Egypt toward the practice. Int J Gynaecol Obstet. 2013;120(3):275-8. https://doi.org/10.1016/j. ijgo.2012.10.010

10. Tag-Eldin MA, Gadallah MA, Al-Tayeb MN, Abdel-Aty M, Mansour E, Sallem M. Prevalence of female genital cutting among Egyptian girls. Bull World Health Organ. 2008;86(4):269-74.

11. Koski A, Heymann J. Changes in support for the continuation of female genital mutilation/cutting and religious views on the practice in 19 countries. Glob Public Health. 2019;14(5):696-708. https://doi.org/10.1080/ 17441692.2018.1542016.

12. Denison E, Berg RC, Lewin S, Fretheim A. Effectiveness of interventions designed to reduce the prevalence of female genital mutilation/cutting. Oslo: Knowledge Centre for the Health Services at The Norwegian Institute of Public Health; 2009. http://www.ncbi.nlm.nih.gov/books/NBK464894/. Accessed 15 Feb 2020.

13. Modrek S, Liu JX. Exploration of pathways related to the decline in female circumcision in Egypt. BMC Public Health. 2013 Oct 3;13:921. https://doi.org/ 10.1186/1471-2458-13-921.

14. Allam MF, de Irala-Estévez J, Fernández-Crehuet Navajas R, Serrano del Castillo A, Hoashi JS, Pankovich MB, Rebollo Liceaga J. Factors associated with the condoning of female genital mutilation among university students. Public Health. 2001:115(5):350-5. https://doi.org/10.1038/s.ph.1900791.

15. Abolfotouh SM, Ebrahim AZ, Abolfotouh MA. Awareness and predictors of female genital mutilation/cutting among young health advocates. Int J Women's Health. 2015;7:259-69. https://doi.org/10.2147/IJWH.S78664 eCollection 2015.

16. Iliyasu Z, Abubakar IS, Galadanci HS, Haruna F, Aliyu MH. Predictors of female genital cutting among university students in northern Nigeria. J Obstet Gynaecol. 2012;32(4):387-92. https:/doi.org/10.3109/01443615.2012.666582.

17. Small E, Sharma BB, Nikolova SP, Tonui BC. Hegemonic masculinity attitudes toward female genital mutilation/cutting among a sample of college students in northern and southern Sierra Leone. J Transcult Nurs. 2019;19: 1043659619875499. https://doi.org/10.1177/1043659619875499.

18. Akbas M, Birge O, Arslan D, Ozbey EG. Opinions of university students about female genital mutilation in Sudan. East Mediterr Health J. 2019;25(4):225-9. https://doi.org/10.26719/emhj.18.033.

19. Van Rossem R, Meekers D, Gage AJ. Trends in attitudes towards female genital mutilation among ever-married Egyptian women, evidence from the demographic and health surveys, 1995-2014: paths of change. Int J Equity Health. 2016 Feb 24;15:31. https://doi.org/10.1186/s12939-016-0324-X.

20. Muteshi JK, Miller S, Belizán JM. The ongoing violence against women: female genital mutilation/cutting. Reprod Health. 2016 Apr 18;13:44. https:// doi.org/10.1186/s12978-016-0159-3.

21. Rasheed SM, Abd-Ellah AH, Yousef FM. Female genital mutilation in upper Egypt in the new millennium. Int J Gynaecol Obstet. 2011;114(1):47-50. https://doi.org/10.1016/j.ijgo.2011.02.003.

22. Hassanin IM, Saleh R, Bedaiwy AA, Peterson RS, Bedaiwy MA. Prevalence of female genital cutting in upper Egypt: 6 years after enforcement of prohibition law. Reprod BioMed Online. 2008;16(1):27-31. https://doi.org/10. 1016/s1472-6483(10)60396-3.

23. Dalal K, Kalmatayeva Z, Mandal S, Ussatayeva G, Lee MS, Biswas A. Adolescent girls' attitudes toward female genital mutilation: a study in seven African countries. F1000Res. 2018;7:343. https://doi.org/10.12688/ f1000research.14142.1 eCollection 2018.

24. Varol N, Turkmani S, Black K, Hall J, Dawson A. The role of men in abandonment of female genital mutilation: a systematic review. BMC Public Health. 2015:15:1034. https://doi.org/10.1186/s12889-015-2373-2.

25. Mohammed ES, Seedhom AE, Mahfouz EM. Female genital mutilation: current awareness, believes and future intention in rural Egypt. Reprod Health. 2018;15(1):175. https://doi.org/10.1186/s12978-018-0625-1.

26. Ministry of Higher Education and Scientific Research. Higher education in numbers (2014-2017). 2018. http://portal.mohesr.gov.eg/ar-eg/Pages/Highereducation-in-numbers.aspx. Accessed 15 Feb 2020.

\section{Publisher's Note}

Springer Nature remains neutral with regard to jurisdictional claims in published maps and institutional affiliations.

\section{Ready to submit your research? Choose BMC and benefit from:}

- fast, convenient online submission

- thorough peer review by experienced researchers in your field

- rapid publication on acceptance

- support for research data, including large and complex data types

- gold Open Access which fosters wider collaboration and increased citations

- maximum visibility for your research: over $100 \mathrm{M}$ website views per year

At BMC, research is always in progress.

Learn more biomedcentral.com/submissions 